\title{
Local Wisdom-Based Electronic Book on Newton's Law
}

\author{
Trisya Afidah Sukma*1, Mundilarto ${ }^{2}$, Nadia Darma Putri ${ }^{3}$ \\ ${ }^{1,2}$ Postgraduate Program of Physics Education, Yogyakarta State University, Indonesia \\ ${ }^{3}$ Postgraduate Program of Physics Education, State University of Malang, Indonesia \\ *Correspondence address: trisyaasukma@gmail.com
}

\begin{tabular}{|c|c|}
\hline Article Info & ABSTRACT \\
\hline Article history: & This study aims to develop a physics e-book based on local wisdom in \\
\hline $\begin{array}{l}\text { Received: June } 24^{\text {th }}, 2019 \\
\text { Accepted: October } 22^{\text {nd }}, 2019 \\
\text { Published: October } 30^{\text {th }}, 2019\end{array}$ & $\begin{array}{l}\text { Newton's law. This research is research and development }(\mathrm{R} \& \mathrm{D}) \text { using the } \\
4 \mathrm{D} \text { model. The stages are defined, design, development, and disseminate. The } \\
\text { sampling technique used is the purposive sampling of } 36 \text { respondents. At the } \\
\text { define, the stage is done with the preliminary analysis, analysis of learners, }\end{array}$ \\
\hline $\begin{array}{l}\text { Keywords: } \\
\text { local wisdom; } \\
\text { Newton's law; } \\
\text { physics e-book; } \\
\text { research and } \\
\text { development. }\end{array}$ & $\begin{array}{l}\text { task analysis, concept analysis, and formulate learning objectives. In the } \\
\text { design stage, the arrangement of the instrument, media and format selection, } \\
\text { and design of the initial product. The developing stage includes the review by } \\
\text { the supervisor, expert assessment, and product trial. The technique of } \\
\text { collecting data uses a questionnaire. The questionnaire used in this study was } \\
\text { divided into (1) questionnaire on teacher and student needs, (2) product } \\
\text { feasibility questionnaire based on material experts and media experts, (3) } \\
\text { student response questionnaires. The results of this study show that physics e- } \\
\text { book based on local wisdom is very feasible to use in learning physics in } \\
\text { Newton's law material. Based on the research result, learning using e-book } \\
\text { based on local wisdom is learning media innovation that supports education } \\
\text { in the industrial revolution } 4.0 \text { without forgetting local culture. }\end{array}$ \\
\hline
\end{tabular}

(C) 2019 Physics Education Department, UIN Raden Intan Lampung, Indonesia

\section{INTRODUCTION}

Mckinsey digital research (Bauer, 2016) provides advice that everyone should prepare mentally (Suwardana, 2018) and skills to face the industrial revolution 4.0 era, by having good competence, increasing selfcompetence (Muhali, 2018; Syafii \& Musri, 2019) and having a literacy skill (Meliantina, 2019; Subekt, Taufiq, Susilo, Ibrohim, \& Suwono, 2017). Provisions of selfpreparation can be through education (lifelong-education) and self-concept through conversation experience of cooperation (Suwardana, 2018).

In physics learning, four important elements need to be understood and known by students, including material and their interactions, force and their interactions, energy, waves and their applications (National Research Council., 2012). Newton's law is one of the materials included in the important elements of force and their interactions, so concepts understanding of Newton's law is very important to be developed in learning and becomes the main focus for students to learn (Muna, 2015). However, in reality, there are still many students who have a low understanding of Newton's law (Saglam-Arslan \& Devecioglu, 2010).

Along with the development of technology and communication, it is now entering the era of Industrial Revolution 4.0, where the development of science and technology is very rapid and has a major impact on all aspects of human life, one of them is education (Suseno \& Riswanto, 2017). This is caused by the development of technology that helps teachers to be easier in delivering teaching material (Sudarsono \& Krisnawati, 2014). The development of technology requires the teacher to be able to 
use the results of these technologies as learning media (Setiadi, Yuliatmojo, \& Nurhidayat, 2018).

Nowadays, there's been a lot of learning media based on technology, one of them is Mobile Learning (M-Learning). M-learning evolved as a result of the development of telecommunications technology, namely, the smartphone. Android is a smartphone that was popular (Riswanto \& Dewi, 2017). The utilization of android as a media of learning will have an impact on improving the academic performance of high school students (Yektyastuti \& Ikhsan, 2016). Learning physics-based on android can make one of the interesting learning media because students can learn the material by utilizing the android as the source of learning and access the learning resources wherever he is. Also, students can learn without limited time, students can learn outside of class, so it will give a positive impact on students (Fatimah \& Mufti, 2014).

Based on the results of the questionnaire from 36 respondents of class X SMAN 1 Klaten, all of which have computers/laptops and smartphones obtained results, that is $100 \%$ choose to learn to use audio-visual media because $68 \%$ felt learning media helps to improve the knowledge of physics, and $32 \%$ feel helping to improve physics knowledge. Furthermore, 55\% felt happy and $44 \%$ feel very happy if the material physics taught through local wisdom. $45 \%$ feel the need and $51 \%$ feel very much in need of ebook learning resources for physics learning.

Teachers are required to provide various skills based on wisdom values. So, students do not reject the substance of the industrial revolution 4.0 and continue to receive various advances but are filtered with the values of wisdom (Suyahman, 2019). From the results of the needs analysis, it was decided to research the development of learning media in the form of an androidassisted physics e-book based on local wisdom.

The application of local wisdom in learning can be realized and supported by state policy, for example, government regulation No. 17 the year 2010 regarding management education. The regulation states that education based on local wisdom has been supported by state policy. Learning based on local wisdom can stimulate the thinking skills of learners to integrate science with culture (Güney \& Seker, 2012). Learning physics which is integrated with local wisdom can achieve learning objectives more effectively (Hartini, Misbah, Helda, \& Dewantara, 2017; Kurniawati, Wahyuni, \& Putra, 2017).

The traditional game is part of the local wisdom. One of the local wisdom that can be used in learning physics is a game Manatahan and Nekeran. Manatahan is a traditional game that consists of a heap of broken stone and a ball. Nekeran is another name of the game of marbles. This game can be played together without any limitation of the number of players. This traditional game is also scattered in various regions of Indonesia. Physics lessons are quite abstract, will be more easily imagined and remembered when described with local wisdom (Delima, Warsono, Supahar, \& Jumadi, 2018).

The results of Wu's research $(\mathrm{Wu} \&$ Perng, 2016) reveal notable effects of mobile learning perception on study habits and continuous learning that students would present higher continuance intention of mobile learning when they perceive the usefulness of mobile learning. Besides, reducing text descriptions and increasing animation or sound allow students to interpretation at the same time. Hyunjeong's research (Lee et al., 2016) found that mobile learning develops cooperative thinking skills. The results of the study conducted by Pixyoriza (Pixyoriza, 2018), obtained very feasible criteria on digital book learning media according to the validator and very interesting criteria based on the students' responses to digital books.

Learning physics using e-book based on local wisdom has never been developed so researchers are interested in developing it. Through this research is expected to produce 
a valid physics e-book for use in learning physics in Newton's law material. The benefit of the development of this e-book is to provide real problems in Newton's law material physics lessons so that it is more easily understood. Besides providing input for teachers as an alternative media learning physics that is fun and can be used to increase students' motivation to learn physics.

\section{METHODS}

This study used to research and development (R\&D) method with the 4D model (Define, Design, Develop, and Disseminate). The define stages are initial analysis, analysis of students, task analysis, concept analysis, and formulating learning objectives. In the design stage, instrument preparation, media selection, format selection, and initial product design were carried out. The developing stage includes the review stage by the supervisor, expert assessment, and product testing. At the disseminated stage it shares the final product to teachers and students.

The sampling technique used is the purposive sampling of 36 respondents. The technique of collecting data used a questionnaire. The questionnaire used in this study was divided into (1) questionnaire on teacher and student needs, (2) product feasibility questionnaire based on material experts and media experts, (3) student response questionnaires.

The product feasibility questionnaire uses a four-point rating format. Each feasibility indicator has its criteria. If three criteria are met, then there will be 4 points if two criteria are met, then there will be 3 points, and so on. Product feasibility indicators can be seen in the following Table 1.

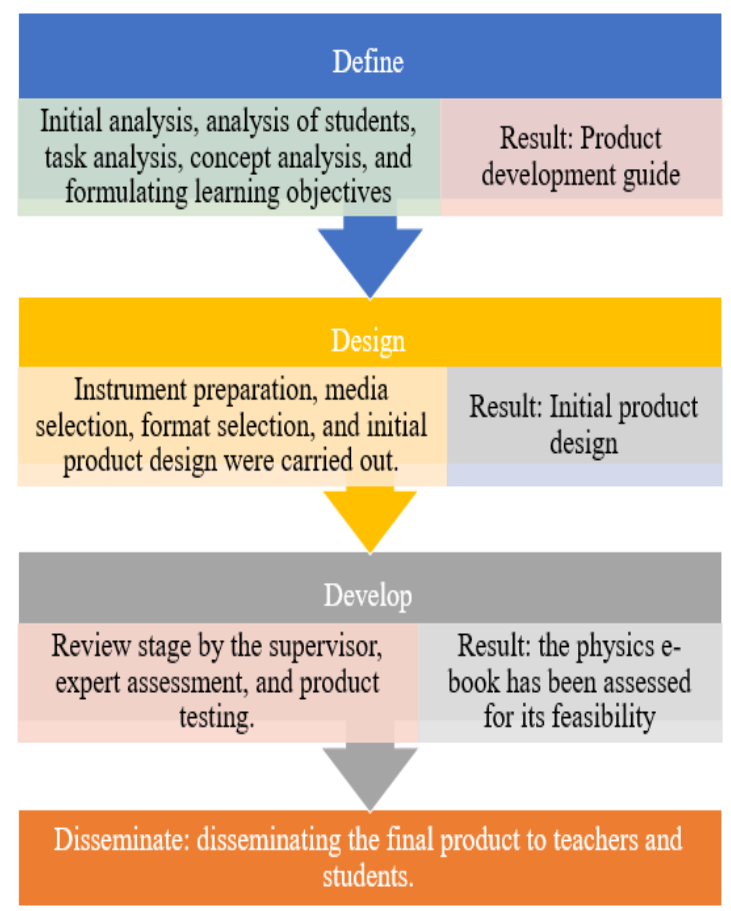

Figure 1. Research design

Table 1. Indicators of the feasibility of the product

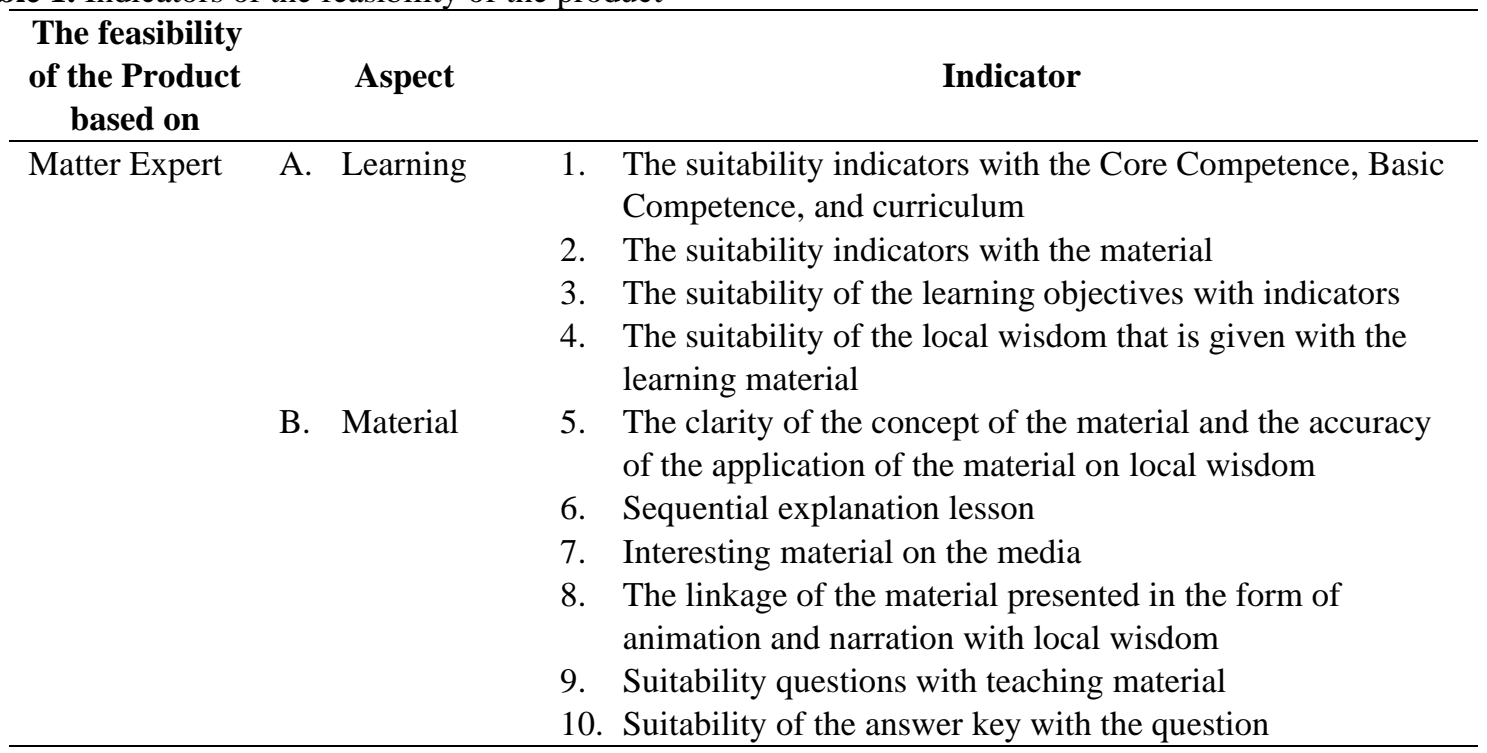




\begin{tabular}{|c|c|c|}
\hline $\begin{array}{c}\text { The feasibility } \\
\text { of the Product } \\
\text { based on }\end{array}$ & Aspect & Indicator \\
\hline \multirow{13}{*}{ Media Expert } & \multirow[t]{3}{*}{ Language } & 11. Accurate use of grammar \\
\hline & & $\begin{array}{l}\text { 12. Accurate selection of sentences used (not multiple } \\
\text { interpretations) }\end{array}$ \\
\hline & & 13. The accuracy of the use of symbols and physics equations \\
\hline & \multirow{7}{*}{$\begin{array}{l}\text { Audiovisual } \\
\text { display }\end{array}$} & 1. Complete identity \\
\hline & & 2. Suitability of layout proportion \\
\hline & & 3. Suitability of color proportion \\
\hline & & 4. Suitability of background selection \\
\hline & & 5. Suitability of font selection \\
\hline & & 6. Consistency of button display \\
\hline & & 7. Clarity of media usage instructions \\
\hline & \multirow{3}{*}{$\begin{array}{l}\text { Software } \\
\text { engineering }\end{array}$} & 8. Ease of access \\
\hline & & 9. Creativity and innovation \\
\hline & & $\begin{array}{l}\text { 10. Opportunities for media development towards the } \\
\text { development of science and technology }\end{array}$ \\
\hline
\end{tabular}

Student questionnaire responses use a four-point format from the Likert scale. Indicators of student response questionnaires are presented in Table 2.
The questionnaire results are analyzed quantitatively according to the indicators that have been set. Each indicator has a predetermined score.

Table 2. Indicators of the questionnaire for student's responses

\begin{tabular}{lll}
\hline \multicolumn{1}{c}{ Aspect } & \multicolumn{1}{c}{ Indicator (Statements) } \\
\hline Display & 1. Text can be read clearly \\
& 2. The picture presented is clear \\
& 3. The image presented is interesting \\
& 4. The video presented is clear \\
& 5. The video presented is interesting \\
& 6. Voice/narration can be heard clearly \\
Material & 7. The learning material is presented clearly and easily understood \\
presentation & 8. The learning material is related to traditional games of \\
& 9. Manatahan and Nekeran \\
Media & 10. The language used is easy to understand \\
operation & 11. Physics e-book can be accessed easily via Android \\
& 12. Physics e-book can be operated/used easily \\
Benefits of & 13. The button feature works properly \\
media & 14. I find it easier to learn using this physics e-book \\
& 15. I can understand the material easily using this physics e-book \\
& 16. This physics e-book helps me understand Newton's law \\
\hline
\end{tabular}

Furthermore, a quality category based on an analysis of physics e-books based on local wisdom is given in the following steps:

1. Calculate the average score $(\bar{X})$ of each item for all aspects, namely the total score of the overall assessment aspect $\left(\sum x\right)$ is divided by the number of assessors or responses $(n)$. (Equation 1)

$\bar{X}=\frac{\sum x}{n}$
2. The average value of each aspect score obtained is then converted into qualitative data in the form of product feasibility. Guidelines for converting scores to five-scale score as shown in Table 3.

Table 3. Quality category conversions

\begin{tabular}{cc}
\hline Interval Score $(\boldsymbol{i})$ & Category \\
\hline $\bar{X}>M_{i}+1,8 S D_{i}$ & Very feasible
\end{tabular}




$$
\begin{aligned}
& M_{i}+0,6 S D_{i}<\bar{X} \leq M_{i}+1,8 S D_{i} \quad \text { Feasible } \\
& M_{i}-0,6 S D_{i}<\bar{X} \leq M_{i}+0,6 S D_{i} \quad \text { Quite feasible } \\
& M_{i}-1,8 S D_{i}<\bar{X} \leq M_{i}-0,6 S D_{i} \quad \text { Less feasible } \\
& \begin{array}{rr}
\bar{X} \leq M_{i}-1,8 S D_{i} & \text { Very less feasible } \\
& \text { (Widoyoko, 2017) }
\end{array} \\
& \text { Description : } \\
& \bar{X} \quad=\text { average score } \\
& M_{i}=\text { mean ideal } \\
& =1 / 2(\text { ideal } \max \text { score }+ \text { ideal } \min \\
& \text { score) } \\
& S D_{i}=\text { standard deviation } \\
& =1 / 6 \text { (ideal } \max \text { score } \text { - ideal min } \\
& \text { score) }
\end{aligned}
$$

The feasibility test in this study used 8 validators. The maximum score on each item is 4 and the minimum score is 1 . Based on the description in Table 3, the $M_{i}$ value is 20 and the $S D_{i}$ is 4 . The feasibility categories in this study can be seen in Table 4 .

Table 4. Range of quality of product feasibility

\begin{tabular}{cc}
\hline Range & Category \\
\hline $\bar{X}>27.2$ & Very feasible \\
$22.4<\bar{X} \leq 27.2$ & Feasible \\
$17.6<\bar{X} \leq 22.4$ & Quite feasible \\
$12.8<\bar{X} \leq 17.6$ & Less feasible \\
$\bar{X} \leq 12.8$ & Very Less feasible \\
\hline
\end{tabular}

\section{RESULTS AND DISCUSSION}

The results of product development are explained in 4 stages of the 4D development model.

\section{Define stage}

At this stage, the needs of students and teachers are defined in the physics learning process so that it can be adapted to the activities of developing a physics e-book based on local wisdom. This activity is to find out the problems encountered in physics learning. This is done so that the product development that will be carried out can provide solutions for students in overcoming the problems faced in physics learning. To obtain this information, the researcher provides a sheet of teacher and student needs (questionnaire). Activities at the defining stage of the initial analysis obtain the following data:

a. The initial analysis was conducted at SMAN 1 Klaten. This school has implemented the 2013 Revised Curriculum in the 2018-2019 school year, so the development of a physics e-book based on local wisdom will refer to the rules in the revised 2013 curriculum.

b. When reviewed in classroom learning activities, the use of technology in learning has not been maximally given. Even though the school environment is sufficient enough to integrate technology in learning. Integrating technology in learning is useful for getting students to use technology wisely. Technology in learning is very important because in 21 stcentury learning it makes students aware of the technology.

c. The results of the questionnaire for students' needs, it was found that all students had used smartphones. The use of smartphones is allowed in the school environment and schools facilitate hotspots for teachers and students.

d. The teacher still uses conventional teaching techniques through the lecture method and writes on the board. Teachers rarely use and develop learning media as supplementary learning material.

e. Learning that is carried out is still teachercentered, so there is a lack of interaction between students. Whereas in 2013 curriculum learning was demanded active and student-centered learning.

f. The teacher still explains learning using only textbooks. The textbooks do not provide contextual physics explanations that are close to everyday life. Though there are so many examples of learning physics that are close to the daily lives of students. Explaining contextual examples through local wisdom is the right way.

g. Students know the existence of local wisdom in the form of traditional games. Of all the students who were given the questionnaire, they were aware of the $95 \%$ defense and employment game, but not all students had played it. Manatahan and Nekeran games are not something foreign in the environment of students. So that integrating physics learning based on 
local wisdom Manatahan and Nekeran will be more easily understood by students.

h. Constraints faced by students in physics learning. The results of the interview activities on students, it was found that students felt difficulties in applying and choosing equations in solving the given physics problems. Students are used to memorizing physics equations rather than understanding the concepts learned. Though physics learning is very close to the use of equations that need to understand the concept to solve a problem. Based on the results of the initial analysis above, then further physics e-books based on local wisdom developed. Some problems encountered in the initial analysis activities can be minimized by the existence of physics e-books based on local wisdom.

\section{Design stage}

At this stage, researchers design a physics e-book based on local wisdom. The results obtained at this stage are:

a. The material developed in physics ebooks based on local wisdom is Newton's law in core competence number 3.7 Revised 2013 curriculum.

b. Using local wisdom Manatahan and Nekeran to convey the physics learning in Newton's law material.

c. Designing a physics e-book based on local wisdom made in the form of an application on an Android smartphone. The preparation of media is preceded by development guidelines, flowcharts, and storyboards. Components in the physics ebook based on local wisdom consist of competencies, content, references, developer profiles, and quizzes as listed in Table 5.

Table 5. Components in the physics e-book based on local wisdom

\begin{tabular}{lcc}
\hline No & Section & \multicolumn{1}{c}{ Information } \\
\hline 1 & Competence & a. Core competence and \\
& & basic competence in the \\
& & 2013 curriculum \\
& & b. Learning indicator \\
\hline
\end{tabular}

\begin{tabular}{|c|c|c|}
\hline No & Section & Information \\
\hline \multirow{7}{*}{2} & \multirow{7}{*}{ Content } & c. Learning objectives \\
\hline & & a. Regarding the game info \\
\hline & & Manatahan and Nekeran \\
\hline & & b. Newton's First Law \\
\hline & & c. Newton's Second Law \\
\hline & & d. Newton's Third Law \\
\hline & & e. Student Discussion Sheet \\
\hline 3 & References & $\begin{array}{l}\text { References used in writing in } \\
\text { the content section }\end{array}$ \\
\hline 4 & Product & Developed product \\
\hline & $\begin{array}{l}\text { information } \\
\text { and }\end{array}$ & $\begin{array}{l}\text { information and developer } \\
\text { profiles }\end{array}$ \\
\hline & $\begin{array}{l}\text { developer } \\
\text { profiles }\end{array}$ & \\
\hline 5 & Quiz & The multiple choices \\
\hline & & $\begin{array}{l}\text { questions of Newton's law } \\
\text { use local wisdom }\end{array}$ \\
\hline
\end{tabular}

The concepts of physics contained in local wisdom Manatahan and Nekeran are presented in Table 6.

Table 6. Physics concepts on local wisdom

\begin{tabular}{|c|c|c|}
\hline Games & Game Activity & $\begin{array}{c}\text { Newton's } \\
\text { Law }\end{array}$ \\
\hline Manatahan & $\begin{array}{l}\text { Players arrange several } \\
\text { pieces of stone like a } \\
\text { tower } \\
\text { Each player rolls the ball } \\
\text { to drop the stone tower } \\
\text { A ball that hits a pile of } \\
\text { stones to collapse }\end{array}$ & $\begin{array}{l}\text { Newton's } \\
1^{\text {st }} \text { Law } \\
\text { Newton's } \\
2^{\text {nd }} \text { Law } \\
\text { Newton's } \\
3^{\text {rd Law }}\end{array}$ \\
\hline Nekeran & 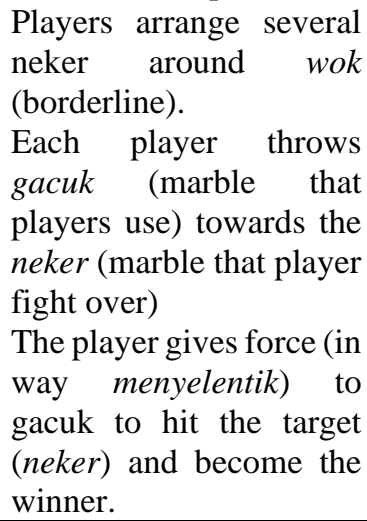 & $\begin{array}{l}\text { Newton's } \\
1^{\text {st }} \text { Law } \\
\text { Newton's } \\
2^{\text {nd }} \text { Law }\end{array}$ \\
\hline
\end{tabular}

\section{Development Stage}

The result of the development stage is a physics e-book based on local wisdom and assessment instruments that have been revised by material experts, media experts, practitioners, and peer reviewers. The results of the development are presented as follows.

a. Early development of physics e-books based on local wisdom 
The development of physics e-books based on wisdom uses Android Studio software. The physics e-book component based on local wisdom developed has an opening, core, and closing section. The opening section consists of the title of a physics e-book based on local wisdom, the Yogyakarta state university (YSU) logo, log in. The core section or content contains an introduction to the game manatahan and nekeran, material, student discussion sheets/SDS (Lembar Diskusi Peserta Didik/LDPD), and quiz. The final section consists of references and developer profiles. For more details, it will be explained below.

\section{1) Home Page}

Figure 2 is the front page of the e-book. The e-book provides logins as teachers and students. This front page shows the ebook title and the YSU logo. The close button can use navigation according to the smartphone, and the teacher and student buttons to start to the main menu.

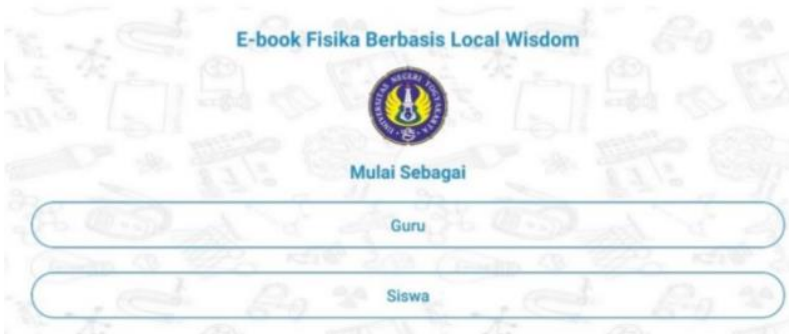

Figure 2. Front view (Home)

If you start as a teacher, the developer creates a teacher password. The appearance can be seen in Figure 3. Because in the teacher login, there are files of lesson planning that can be downloaded, namely: lesson plan, teaching materials, SDS, quizzes and conclusion.

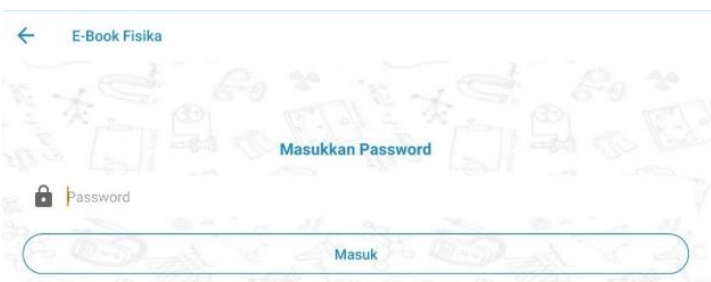

Figure 3. Display entry as teacher

\section{2) Main Page}

Figure 4 shows the display of the main menu page. This page consists of several menus, namely the introduction menu, material, SDS, quizzes, references, and info. This main page presents the same background as the front page.

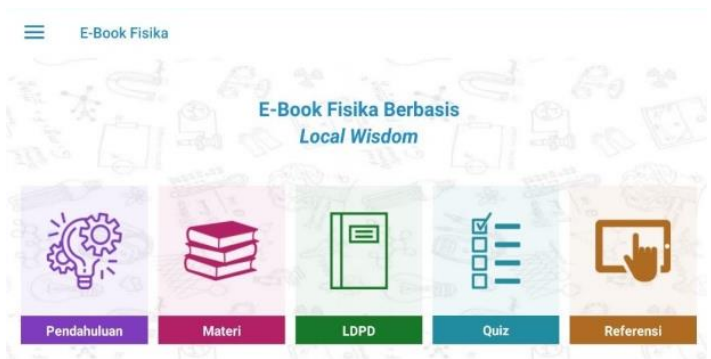

Figure 4. Display of the main menu page

For more details, it will be discussed in detail one by one from the menu presented. The first column from the left is the introduction page. This introductory page contains a menu of core competencies, basic competencies, indicators, learning objectives, and the main map. The difference with the teacher login is located in this menu which is added to the lesson planning submenu. The second column is material, in this menu presents information related to traditional games of manatahan and nekeran in the form of videos. The submenu of this material is the explanation of Law I, II, III Newton related to local wisdom along with examples of the problem (Figure 5 and Figure 6).

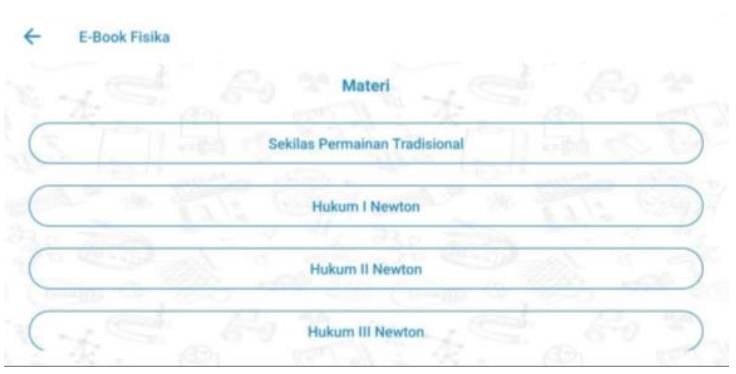

Figure 5. Display of the material menu 


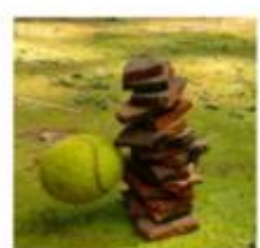

Gambar 10. Bola yang mengenai tumpukan genting

Perhatikan Gambar 10, penjelasan gaya aksi reaksi yang terjadi pada permainan manatahan adalah sebagai berikut: gaya aksi adalah ketika bola mengenai tumpukan genting sehingga genting rubuh. Dalam hal peristiwa ini, bola mengerjakan gaya pada tumpukan genting. Sementara itu, gaya reaksi dari tumpukan genting adalah susunan genting mendorong bola ke arah yang berlawanan sehingga bola terpental atau susunan genting mengerjakan gaya pada bola. Gaya aksi-reaksi ini memiliki nilai yang sama besar. Apabila gaya yang diberikan bola pada tumpukan genting bernilai besar, maka gaya reaksi yang siterima bola dari tumpukan genting juga akan besar. Jika gaya aksi yang diberikan bola kepada tumpukan genting tidak besar, maka gaya reaksi yang diterima bola dari tumpukan genting juga tidak akan besar. Peristiwa ini juga menunjukkan adanya gaya aksireaksi yang bekerja pada dua benda yaoti bola dan tumpukan genting. Pada permainan ini gaya aksi bekerja pada tumpukan genting dan gaya reaksi bekerja pada bola. Secara matematis hukum aksi-reaksi ini dapat dituliskan sebagai berikut:

$$
\sum F_{\text {dat }}=\sum F_{\text {reaki }}
$$

Tanda negatif $(-)$ pada gaya reaksi menunjukkan bahwa gaya reaksi bergerak berlawanan arah dengan gaya aksi.

Figure 6. The examples of Newton's third law material in the game Manatahan

The next column is the SDS menu. This menu presents 3 SDS that will be used in learning. Each SDS is equipped with learning objectives and learning phases that are adapted to the Problem Based Learning (PBL) model. The next column is the quiz menu. The quiz is given 10 multiple choice questions that must be answered first before continuing to the next question (Figure 7). After all the questions are answered, there will be a display of the scores obtained. Finally, the reference menu column. In this column, a list of references is presented, thanks to and e-mail address if there are suggestions and criticisms.

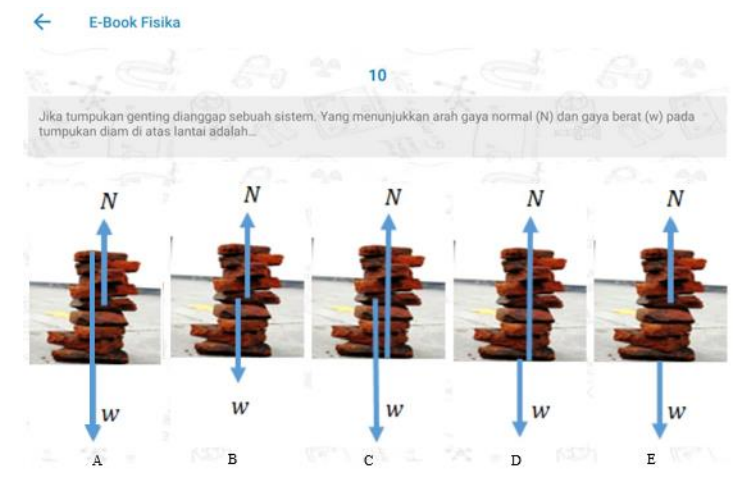

Figure 7. Quiz

The last menu on the main menu page is the information column (Figure 8). This column contains information about physics e-books based on local wisdom and developer profile information. 


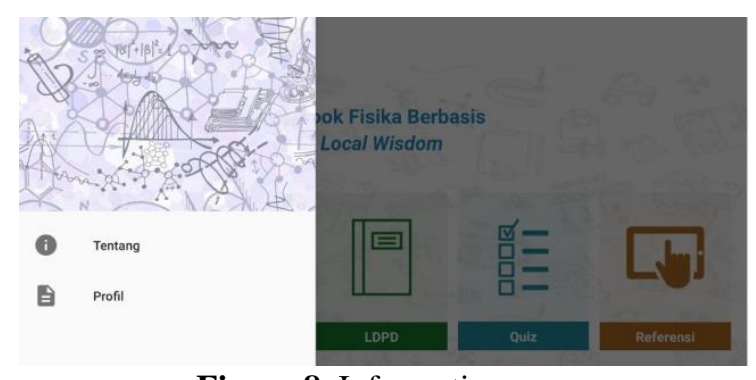

Figure 8. Information menu

\section{b. Local Wisdom Based E-Book Physics Assessment}

Evaluation of the feasibility of physics ebook products based on local wisdom in terms of material and media aspects. Assessment is carried out by material experts, media, practitioners, and peer reviewers. Assessment is carried out to obtain product feasibility based on expert judgment in terms of material and media. The results of the feasibility assessment of physics e-books are based on local wisdom in terms of material and media as follows.

1) Assessment of Material Feasibility

The material on physics e-book based on local wisdom was assessed based on aspects of learning material, material presentation, and language. The material was assessed by two material experts, practitioners, and peer reviewers. The results of the assessment are quantitative and qualitative data. Qualitative data in the form of suggestions and comments that are the material for consideration of product revisions. While quantitative data in the form of scores with ranges (1-4). The results of this assessment were analyzed according to the Raw Scale on a scale of 5 (Table 4).

Assessors provide an assessment in three aspects, namely learning consists of four indicators, aspects of matter consisting of six indicators and aspects of language consists of three indicators. The results of the analysis activities (Table 7) obtained physics e-book products based on local wisdom with an average rating of experts (8 assessors) of $30.31(X)$ from the three aspects of material assessment. The results of the acquisition are categorized as very good.
Table 7. Results of the evaluation of physics e-book material based on local wisdom

\begin{tabular}{ccc}
\hline Aspect & Score $(\overline{\boldsymbol{X}})$ & Category \\
\hline Learning & 30 & Very feasible \\
Material & 30.33 & Very feasible \\
Language & 30.67 & Very feasible \\
Average & 30.31 & Very feasible \\
\hline
\end{tabular}

2) Media Feasibility Assessment

Media on physics e-book products based on local wisdom were assessed based on aspects of product appearance and software engineering. The media is rated by media experts, practitioners and peer reviews. Qualitative data in the form of suggestions and comments that are the material for consideration of product revisions. While quantitative data in the form of scores with ranges (1-4). Assessment results are analyzed according to the standard scale on a scale of 5 (Widoyoko, 2017).

The results of the analysis (Table 8) obtained that the product of physics ebook based on local wisdom with an average rating of experts ( 8 assessors) of $30.3(X)$ from the two aspects of material assessment. The results of the acquisition are categorized as very feasible.

Table 8. Results of an evaluation of physics e-book media based on local wisdom

\begin{tabular}{ccc}
\hline Media Aspect & Score $(\overline{\boldsymbol{X}})$ & Category \\
\hline E-book Display & 30.1 & Very feasible \\
Software & 30.7 & Very feasible \\
Engineering & 30.3 & Very feasible \\
Average &
\end{tabular}

Suggestions obtained related to the appearance of physics e-books related to background proportions, color and size of writing that is still not suitable, so it needs to be corrected. The physics e-book component includes the title, YSU logo, developer profile, introduction, material description, SDS, quiz, and closing is good. 
3) Questionnaire for the Response of Students

As many as 10 students as respondents were asked to use physics e-books based on local wisdom. After that, the students were asked to fill out a questionnaire about the use of the physics e-book. Students provide an assessment of the value range of 1 to 4 . The results were analyzed using the standard deviation of the response ideal score (Sbi). The range of scores in Table 9 is based on calculations in Table 3.

Table 9. Range of quality of product feasibility in student response

\begin{tabular}{cc}
\hline Range & Category \\
\hline $\bar{X}>34$ & Very feasible \\
$28<\bar{X} \leq 34$ & Feasible \\
$22<\bar{X} \leq 28$ & Quite feasible \\
$16<\bar{X} \leq 22$ & Less feasible \\
$\bar{X} \leq 16$ & Very Less feasible \\
\hline
\end{tabular}

The analysis is done when how to operate physics e-book physics on their android (at least version 4.0). The results were obtained: 1) physics e-book is very good at running on Android learners with the kind of brand mobile phone is different, 2) does not happen constraints such as bugs, errors, or jammed by the time the physics e-book opened and used, 3) students are able to adapt directly to the operation of physics e-book. In addition to giving an assessment, students also comment on the physics e-book. The conclusions of the comments given by the students are: 1) physics e-book is good, interesting and nice, 2) physics e-book is easy to understand and can be used as teaching material, 3) android-assisted physics e-book can increase student learning interest, 4) the quality of e-book physics needs to be improved and this physics e-book is an interesting learning media innovation.

Table 10. Results of student response assessment

\begin{tabular}{lcc}
\hline \multicolumn{1}{c}{ Aspect } & Score $(\overline{\boldsymbol{X}})$ & Category \\
\hline Display & 35.5 & Very feasible \\
Material & 38 & Very feasible \\
presentation & 38 & Very feasible \\
Operation & 32.8 & Feasible \\
Benefits of Media & 35.72 & Very feasible \\
Average & & \\
\hline
\end{tabular}

In Table 10 above, the test results physics e-book local wisdom-based android-assisted to 10 learners obtain excellent results in the aspect of appearance, presentation materials, and the operation of the media. While the benefits of the media get an average score of 32.8 , it is categorized as very feasible. This means that students understand enough how the work and physics e-books can be applied well to students.

\section{Disseminate}

The main objectives of the dissemination of this product are teachers and students. This is one way to provide innovation in the world of education, especially physics education by integrating traditional technology and games in the world of education.

According to Istifarida's research (Istifarida, Santoso, \& Yusup, 2017), the results show that students have a high interest in learning geographic material when it is packaged attractively and easily understood in the form of e-books. Ghofur's research (Ghofur \& Kustijono, 2015) obtained the results of students' positive responses of $88.89 \%$ in the very feasible category. Furthermore, students are asked to solve problems that exist in the e-book, and the results are $87.5 \%$ of students can solve the evaluation questions with a minimum value of 75. The e-book developed by Pratiwi (Pratiwi, 2017) obtained a 90\% student response at the excellent category and can help students understand chemistry.

The development of this physics e-book has been made interesting and easy to learn. Physics e-books can provide better understanding because the subject matter described is better than using print media. Students can read, hear, see and do what is exemplified in the pictures/videos and analyze the problems that are given to make students more active in receiving lessons. In this research, a local wisdom-based physics e-book was developed, which is integrating traditional games of Manatahan and Nekeran as a source of learning physics so that 
students are easier to understand the physics of Newton's law material.

\section{CONCLUSION}

The results of the feasibility test of the ebook based on local wisdom by media experts obtained a result of 30.3 with a very feasible category. The results of the feasibility test by material experts are 30.31 with a very feasible category. The results of the questionnaire responses of students obtained a score of 35.72 with a very feasible category. Based on the results of the feasibility study, it can be concluded that the physics local wisdom based e-book on Newton's laws of material suitable as a media of learning physics by students of class $\mathrm{X}$ SMA and equal.

\section{AUTHOR CONTRIBUTIONS}

TA conceptualizes ideas and develops research designs. TA and SN make e-book media. RM distributes questionnaires, collects data, and analyzes data. SN performs calculations, as well as describes the results and discussion.

\section{REFERENCES}

Bauer, H. B. (2016). Industry 4.0 After The Initial Hype-Where Manufacturers are Finding Value and How They Can Best Capture It. McKinsey Digital.

Delima, E., Warsono, Supahar, \& Jumadi. (2018). The Importance of Multimedia Learning Modules (Mlms) Based on Local Wisdom as an Instructional Media of 21st Century Physics Learning. Journal of Physics: Conference Series, 1097(1). https://doi.org/10.1088/17426596/1097/1/012018

Fatimah, S., \& Mufti, Y. (2014). Pengembangan Media Pembelajaran IPA-Fisika Smartphone Berbasis Android sebagai Penguat Karakter Sains Siswa. Jurnal Kaunia, 10(1), 5964.

Ghofur, A., \& Kustijono, R. (2015). Pengembangan E-Book Berbasis Flash
Kvisoft Flipbook pada Materi Kinematika Gerak Lurus Sebagai Sarana Belajar Siswa SMA Kelas X. Inovasi Pendidikan Fisika, 04(02), 176180.

Güney, B. G., \& Seker, H. (2012). The use of History of Science as A Cultural Tool to Promote Students' Empathy with The Culture of Science. Educational Sciences: Theory \& Practice, 12(1), 533-539.

Hartini, S., Misbah, Helda, \& Dewantara, D. (2017). The Effectiveness of Physics Learning Material Based on South Kalimantan Local Wisdom. AIP Conference Proceedings, 1868(August). https://doi.org/10.1063/1.4995182

Istifarida, B., Santoso, S., \& Yusup, Y. (2017). Pengembangan E-Book Berbasis Problem Based Learning-GIS untuk Meningkatkan Kecakapan Berfikir Keruangan pada Siswa Kelas X SMA N 1 Sragen 2016/2017. Jurnal GeoEco, 03(02), 113-114. https://doi.org/10.20961/paedagogia.v2 0vi2.8596

Kurniawati, A. A., Wahyuni, S., \& Putra, P. D. A. (2017). Utilizing of Comic and Jember's Local Wisdom as Integrated Science Learning Materials. International Journal of Social Science and Humanity, 7(1), 47-50. https://doi.org/10.18178/ijssh.2017.7.1. 793

Lee, H., Parsons, D., Kwon, G., Kim, J., Petrova, K., Jeong, E., \& Ryu, H. (2016). Cooperation Begins: Encouraging Critical Thinking Skills Through Cooperative Reciprocity using A Mobile Learning Game. Computers and Education, 97, 97-115. https://doi.org/10.1016/j.compedu.2016 .03 .006

Meliantina. (2019). Menerapkan Budaya Literasi Guru Sekolah dalam Upaya Meningkatkan Pendidikan di Era Industri 4.0. Murobbi: Jurnal Ilmu Pendidikan, 3(2), 120-139. 
Muhali, D. (2018). Arah Pengembangan Pendidikan Masa Kini Menurut Perspektif Revolusi Industri 4.0. Seminar Nasional Lembaga Penelitian Dan Pendidikan (LPP) Mandala, (September), 1-14.

Muna, I. A. (2015). Newton Menggunakan Certainty of Response Index (CRI). Cendekia, 13.

National Research Council. (2012). A Framework for K-12 Science Education: Practices, crosscutting Concepts, and Core Ideas. National Academies Press.

Pixyoriza. (2018). Pengembangan Media Pembelajaran Digital Book Menggunakan Kvisoft Flipbook Berbasis Problem Solving. Universitas Raden Intan.

Pratiwi, A. (2017). Pengembangan E-book Berbasis Metakognisi Menggunakan 3D Pageflip pada Materi Ikatan Kimia di Kelas X MIPA SMA Negeri 1 Muaro Jambi. Artikel Universitas Jambi.

Riswanto, R., \& Dewi, N. A. K. (2017). Peningkatan Keterampilan Proses Sains melalui Pembelajaran Berbasis Laboratorium untuk Mewujudkan Pembelajaran Berkarakter. Jurnal Riset Dan Kajian Pendidikan Fisika, 4(2), 60. https://doi.org/10.12928/jrkpf.v4i2.816 4

Saglam-Arslan, A., \& Devecioglu, Y. (2010). Student Teachers' Levels of Understanding and Model of Understanding about Newton's Laws of Motion. Asia-Pacific Forum on Science Learning and Teaching, 11(1), 1-20.

Setiadi, A., Yuliatmojo, P., \& Nurhidayat, D. (2018). Pengembangan Aplikasi Android untuk Pembelajaran Pneumatik. Jurnal Pendidikan Vokasional Teknik Elektronika, I(1), 15.

Subekt, H., Taufiq, M., Susilo, H., Ibrohim, I., \& Suwono, H. (2017). Mengembangkan Literasi Informasi Melalui Belajar Berbasis Kehidupan Terintegrasi STEM untuk Menyiapkan
Calon Guru Sains dalam Menghadapi Era Revolusi Industri 4.0: Revieu Literatur. Education and Human Development Journal, 3(1), 81-90. https://doi.org/10.33086/ehdj.v3i1.90

Sudarsono, M. A., \& Krisnawati, K. (2014). Analisis dan Perancangan Aplikasi "Fun 2D Shapes Learning" Berbasis Mobile Android. Data Manajemen dan Teknologi Informasi (DASI), 15(2), 35.

Suseno, N., \& Riswanto, R. (2017). Program Optimalisasi Peran Laboratorium Fisika SMA di Kota Metro, Lampung. Jurnal Pengabdian Pada Masyarakat, 2(2), 149-158.

https://doi.org/10.30653/002.201722.28

Suwardana, H. (2018). Revolusi Industri 4.0 Berbasis Revolusi Mental. JATI UNIK: Jurnal Ilmiah Teknik Dan Manajemen Industri, $\quad 1(1), \quad 102$. https://doi.org/10.30737/jatiunik.v1i2.1 17

Suyahman, S. (2019). Peningkatan mutu pembelajaran PPPKn melalui pendekatan pembelajaran Aktif, Bahagia, Asyik, Humanis, Kreatif dan Unik (ABAHKU) bagi siswa smp negeri 1 boyolali tahun pelajaran 20172018. PKn Progresif: Jurnal Pemikiran dan Penelitian Kewarganegaraan, 14(2), 91-108.

Syafii, M., \& Musri, M. A. (2019). Meningkatkan Kemampuan Mahasiswa sebagai Sumber Daya Manusia Yang Siap Menghadapi Era Industri 4.0. Prosiding Seminar Nasional Era Industri (SNEI) 4.0, 1(1), 70-76. Retrieved from http://ejournal.upmi.ac.id/index.php/sn ei/article/view/35/25

Widoyoko, S. E. (2017). Teknik Penyusunan Instrumen Penilaian (6th ed). Yogyakarta: Pustaka pelajar.

Wu, W. C., \& Perng, Y. H. (2016). Research on the Correlations Among Mobile Learning Perception Study Habits, and Continuous Learning. Eurasia Journal of Mathematics, Science and Technology Education, 12(6), 1665- 
1673.

https://doi.org/10.12973/eurasia.2016.1 $556 \mathrm{a}$

Yektyastuti, R., \& Ikhsan, J. (2016).

Developing Android-Based

Instructional Media of Solubility to
Improve Academic Performance of High School Students. Jurnal Inovasi Pendidikan IPA, 2(1), 88-99. https://doi.org/10.21831/jipi.v2i1.1028 9 